\title{
Artificial intelligence in urban services in Malaysia: a review
}

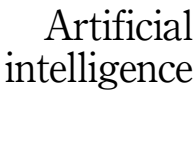

\author{
Mohamad Shaharudin Samsurijan, Andrew Ebekozien, \\ Noor Alyani Nor Azazi, Maslina Mohammed Shaed and \\ Radin Firdaus Radin Badaruddin \\ Development Planning and Management, School of Social Sciences, \\ Universiti Sains Malaysia, Pulau Pinang, Malaysia
}

Received 12 July 2021 Revised 11 January 2022 Accepted 12 February 2022

\begin{abstract}
Purpose - Studies showed that a proactive delivery system employing innovative artificial intelligence (AI) in urban services might perform better. This has become an important national policy for many countries. Thus, this study aims to explore the influence of AI in urban services in Malaysia.

Design/methodology/approach - Official documents such as Structure Plan and Government Transformation Programme Policy Document covering various levels of cities in Malaysia, articles related to urban studies mostly written by researchers regarding urban growth in Malaysia and the Urban Development Bulletin from the Federal Department of Town and Country Planning from 1957 to date were reviewed and analysed.

Findings - The findings show that the influence of AI in urban services has long existed and been carefully planned by local authorities since colonial times. The development of global digital technology influences the upgrading of AI in urban services in Malaysia. Also, the success of AI in these municipal services is influenced by the rate of information technology literacy among the urban population. These developments have led to the definition of a conceptual city.

Research limitations/implications - This paper's findings and conclusion were based on reviewed literature but did not compromise the strength of this paper. Thus, as part of the implications for future research, mixed-methods research design has been suggested.

Practical implications - As part of the implications, this article intends to promote AI in urban services in Malaysia and other developing countries with similar urban services challenges.

Originality/value - This paper encourages AI applications in urban services because it enhances service delivery performance. This intends to key stakeholders to promote AI via policies across Malaysia's urban services as part of the study implications.
\end{abstract}

Keywords Artificial intelligence, Development, Digitalisation, Malaysia, Urbanisation, Urban services

Paper type Literature review

\section{Introduction}

Today, the Industrial Revolution 4.0 (4IR) requires one to accept the reality of advancements in computer technology. Contemporary computer system technology has infiltrated many physical technology systems and human life systems. This is what is known as artificial intelligence (AI). Characteristics of AI are closely related to a computer system programmed to maximise human behaviour and roles (Schalkoff, 1990; Russell and Norvig, 2016). AI is a wide and progressive field that has grasped the entire control of artificial and digital

(C) Mohamad Shaharudin Samsurijan, Andrew Ebekozien, Noor Alyani Nor Azazi, Maslina Mohammed Shaed and Radin Firdaus Radin Badaruddin. Published in PSU Research Review. Published by Emerald Publishing Limited. This article is published under the Creative Commons Attribution (CC BY 4.0) licence. Anyone may reproduce, distribute, translate and create derivative works of this article (for both commercial and non-commercial purposes), subject to full attribution to the original publication and authors. The full terms of this licence may be seen at http://creativecommons.org/licences/by/4.0/ legalcode.

The study is funded by the Ministry of Higher Education Malaysia for Fundamental Research Grant Scheme with Projek Code: FRGS/1/2020/SSO/USM/02/10.

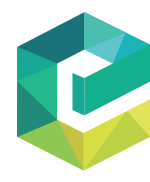

PSU Research Review Emerald Publishing Limited DOI 10.1108/PRR-07-2021-0034 
technology and robotics. Innovations in AI have opened up new research involving efforts in explaining and replicating human behaviour, recording, modelling and storing human intelligence in the information technology system and training or programming systems for carrying out human tasks (Russell and Norvig, 2016). AI is the ability of a computer system programmed in a machine to understand, think and learn in a way similar to humans and possesses intelligence just like humans.

Rapid expansion in the use and application of $\mathrm{AI}$ in the urban services system is not something new. The need for a proactive delivery system that employs innovative AI in government and urban services has become an important national policy (Jenkins, 2000). In Malaysia, the National Transformation Programme (NTP), which involves the urban services sector, reflects the government's efforts to improve the delivery system to implement it directly in society. The Government Transformation Programme (GTP) has been aligned with the principles of the Malaysia Slogan of "People First, Achievement Foremost". The GTP established objectives, projected results and a set of initial actions in fields that have been identified as the National Key Results Area (NKRA) and the Ministry Key Results Area (MKRA) with a specific focus (Malaysia, 2010). GTP's effects have led to the National Broadband Programme and Services Delivery Platform, in the Urban Transformation Centre (UTC), Rural Transformation Centre, Mini Rural Transformation Centre, Government Mobile Application Gallery and myGov Mobile. These transformation programmes have succeeded in improving the urban services system, as presented in Figure 1. The Malaysian Government introduced the GTP Master Plan to empower the government's delivery system and explain in length the core function of delivery services provided to the Malaysian people. It aims to scrutinise the objectives and effectiveness of the delivery system while planning initial actions in the fields identified as the NKRA and the Ministerial Key Results Areas (MKRA) (Malaysia, 2010). Together with the GTP, the National Economy Advisory Council (NEAC) had designed and formed the New Economic Model (NEM) to replace the New Economic Policy (NEP). Whereas, the Economic Planning Unit (EPU) had reviewed the 11th Malaysia Plan (RMK-11) without neglecting the strategies outlined in the 10th Malaysia Plan (RMK-10) (Malaysia, 2010). The GTP was found to portray the overall strategy of the Malaysian government. Hence, the GTP had encouraged the use of AI in most of the government's delivery systems and private agencies, especially private agencies that have a direct relationship with the government's delivery system.

Figure 1.

Malaysia's vision towards a developed nation

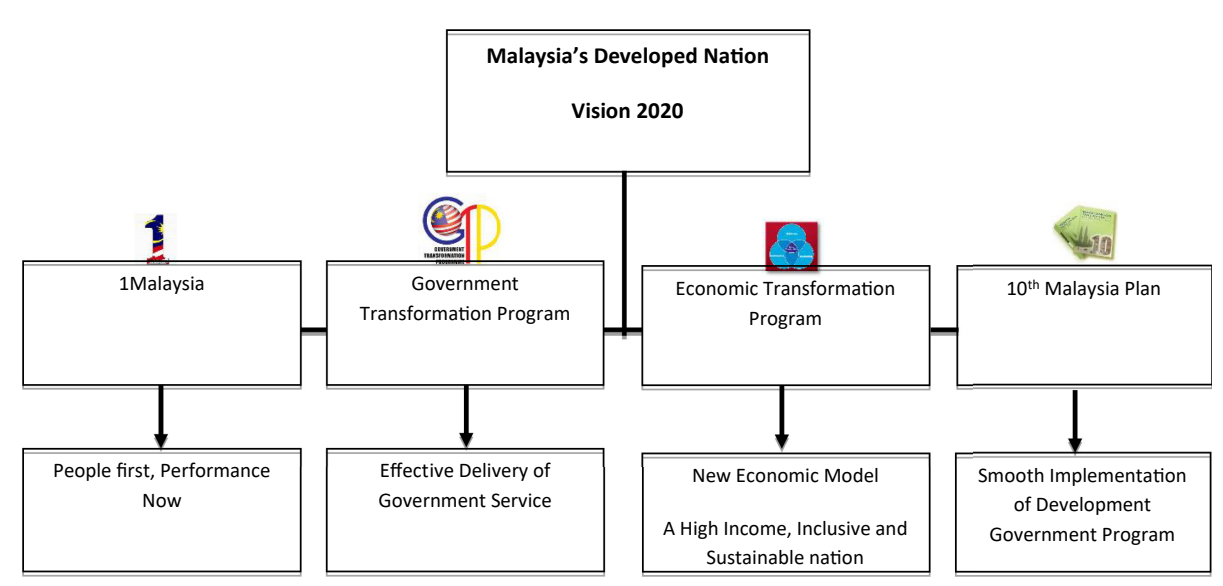

Source(s): Ebekozien (2019, p. 45) 
The newly introduced GTP has contributed immensely to the urban services system in Malaysia, as presented in Figure 2. Public Transport Optimisation, Air Quality Monitoring, Safer Streets for Women, Traffic System Management, Water Leakage Detection, Optimisation of Garbage Collection Recycling and Video Monitoring are examples of programmes AI has been used (Malaysia, 2010). AI plays a huge role in influencing urban services and the administration system in Malaysia. The innovative progress in AI has created a platform that facilitates urban services in the delivery, monitoring, enforcement and community services (Yigitcanlar et al., 2020, 2021; Jenkins, 2000). All these enhanced services form an important core that ensures urban services in Malaysia apply the modern AI approach.

\subsection{Major cities in Malaysia}

There are 38 major cities in Malaysia (Ebekozien, 2019). This comprises of minimum population 100,000 inhabitants and maximum 2,000,000 inhabitants. These cities are located in 13 states throughout Malaysia categorised according to the size of the local authority (LA) administration such as District Council, Municipal Council, City Council and City Hall, as presented in Table 1. Each city has its administration system with limited autonomy to increase revenue, taxation, rent, enforcement and monitoring within the administrative territories designated by the state government (Malaysia, 2010). The State of Penang, Kuala Lumpur and Johor Baharu are the three key important locations of major cities in Malaysia. The George Town City Council (North

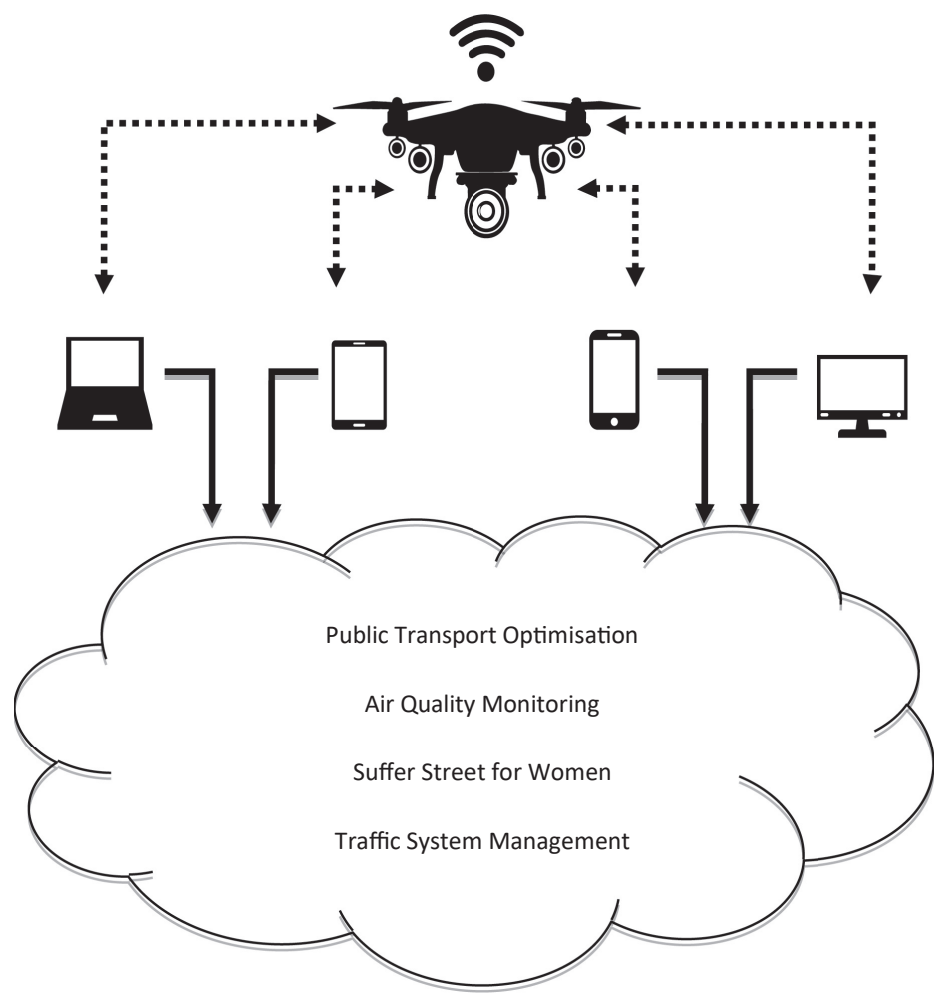

Source(s): Malaysia (2010)
Artificial intelligence 


\section{PRR}

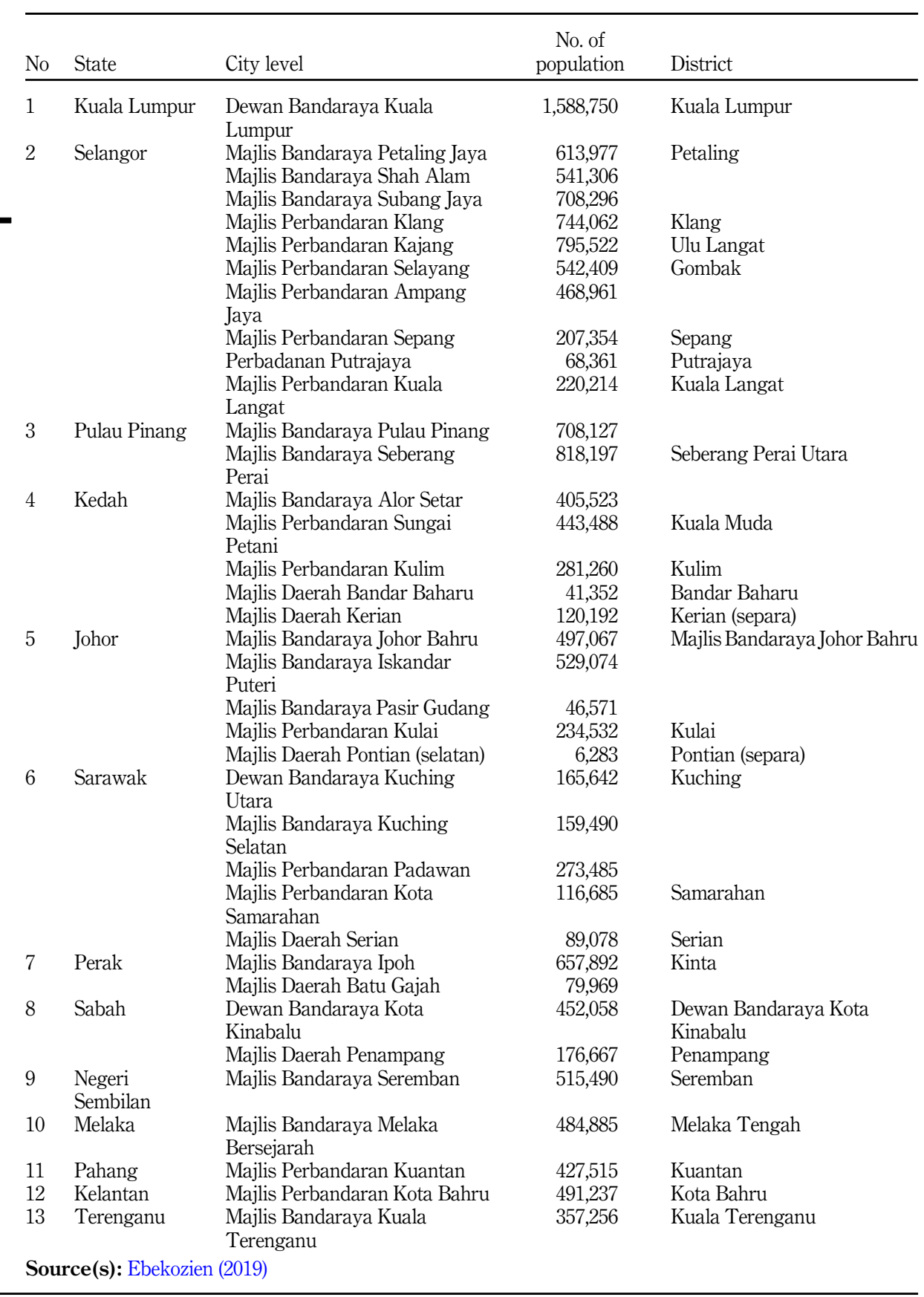

Table 1.

List of main cities in Malaysia 
Malaysia), Kuala Lumpur City Hall (Centre Malaysia) and Johor Bahru City Council (South Malaysia) have played significant roles in influencing the development of the 35 other major cities across Malaysia (Choon et al., 2011). Autonomous powers provided under the Local Government Act 1976 (Act 171) for urban administration throughout Peninsular Malaysia; Local Authorities Ordinance 1996 (Chapter 20) for urban administration in Sarawak; and Local Government Ordinance 1961 (Sabah No. 11 of 1996) for urban administration in Sabah, has enabled LAs to be empowered to plan urban development that has been defined by gazetted boundary areas (Malaysia, 2006a, b). Table 2 summarises the different scope of criteria between city hall, municipal council and district council in Malaysia's context.

Thus, different urban levels influence the development of delivery systems equipped with AI elements. Most past studies such as McGill (1998), Wu and Silva (2010), Abbott (2013), Cugurullo (2020), Ibrahim et al. (2020) found that the influence of AI in the administrative system of cities is influenced by the lifestyle and literacy needs of the community in the area.

\begin{tabular}{|c|c|c|c|}
\hline Criteria & City HALL/council & Municipal council & District council \\
\hline DESCRIPTION & Stated administrative & $\begin{array}{l}\text { Main city or administrative } \\
\text { centre for state or district }\end{array}$ & $\begin{array}{l}\text { Other areas of main } \\
\text { city }\end{array}$ \\
\hline POPULATION & More than 500,000 people & More than 150,000 people & $\begin{array}{l}\text { Less than } 150,000 \\
\text { people }\end{array}$ \\
\hline INCOME & $\begin{array}{l}\text { Fiscally sustainable } \\
\text { Annual income/outcome } \\
\text { not less than MYR } 100 \mathrm{~m} \\
\text { Capable to balance the } \\
\text { expenses }\end{array}$ & $\begin{array}{l}\text { Sustainable in financial } \\
\text { resources } \\
\text { Annual income not less than } \\
\text { MYR20m } \\
\text { Provide comfortable } \\
\text { services }\end{array}$ & $\begin{array}{l}\text { Annual income less } \\
\text { than MYR20m }\end{array}$ \\
\hline SERVICES & Provide high-level services & $\begin{array}{l}\text { Provide space and } \\
\text { opportunities to businesses } \\
\text { to encourage the } \\
\text { development of investment } \\
\text { activities, businesses and } \\
\text { commercialisation }\end{array}$ & $\begin{array}{l}\text { More focus to } \\
\text { public amenities } \\
\text { and infrastructure } \\
\text { facilities }\end{array}$ \\
\hline DEVELOPMENT & $\begin{array}{l}\text { Focus on sustainable } \\
\text { development towards } \\
\text { issues in urbanisation, e.g. } \\
\text { slum, illegal } \\
\text { manufacturing, security, } \\
\text { housing, for lower-income } \\
\text { group } \\
\text { Environmental prevention } \\
\text { as sustainable urban } \\
\text { indicator, e.g. network } \\
\text { indicator for Malaysian } \\
\text { Urban System (MURNInet) }\end{array}$ & $\begin{array}{l}\text { Planning towards } \\
\text { sustainable urban } \\
\text { development and capable to } \\
\text { provide save environment } \\
\text { for a living } \\
\text { Sustainable urban } \\
\text { indicators had been stressed } \\
\text { in network indicator for } \\
\text { Malaysian Urban System } \\
\text { (MURNInet) }\end{array}$ & - \\
\hline $\begin{array}{l}\text { OTHER } \\
\text { INFRASTRUCTURE } \\
\text { AND AMENITIES }\end{array}$ & $\begin{array}{l}\text { Centre of industrialisation } \\
\text { and financial institution, } \\
\text { education with complete } \\
\text { cultural activities, sports } \\
\text { and recreational, including } \\
\text { public parks, especially for } \\
\text { disabled group. And } \\
\text { certified at national level } \\
\text { and international }\end{array}$ & $\begin{array}{l}\text { Encouraging local } \\
\text { community/resident to } \\
\text { develop their community } \\
\text { through good governance } \\
\text { practices, e.g. execution of } \\
\text { Local Agenda (LA21) }\end{array}$ & \\
\hline
\end{tabular}

Source(s): Malaysia (2010)

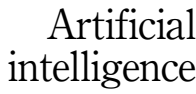


The latter authors explored the study of smart city administration in Malaysia. They argued that the effectiveness of digital and information systems in urban administration would be more meaningful and successful through decision-making authority in urban administration, community participation culture and individual self-discipline. This is one of the reasons the present study argues the need for $\mathrm{AI}$ in the urban delivery system. This should be related to the readiness of the population in the city. This is part of the gaps that have been filled in this paper. This section makes the background of the study and discusses the major cities in Malaysia.

\section{History of artificial intelligence development in Malaysia's urbanisation administration system}

This paper will divide the history of Al's development in Malaysia's urban services system since her independence into five phases. This includes the era after independence (19571970), New Economic Policy (DEB) era (1970-1990), National Development Policy era (19902000), a society based on information and knowledge era (2000an) and the national transformational era (2009-kini).

\subsection{The era after independence 1957-1970}

This was when the Malay States (Malaysia) achieved their independence from the British colony. During this era, there was a paucity of literary evidence or research related to AI connected to the urban services system. However, urban services were under the auspices of the local government, which is the lowest level of governance in the administrative system in Malaysia (Sa'at et al., 2017). Presently, the organisation and governance of local government still maintain British influence. This is because the institutional framework was based on the model implemented in Britain. Thus, several elements, such as legislation and regulation aspects, are similar to British legislation. Before independence, the Local Government Election Ordinance 1950 provided the authority to local councils to organise elections. The Local Government Ordinance 1952 gave authority to local citizens to form their local councils. Towards the end of the British colonisation era, 289 local councils in the Malay States were created (Hussiin, 2009). Whereas after the Malay States achieved independence, the structure of the local government was placed under the States List in the Malay States. The council's function is to carry out the administrative structure and services functions according to each council's stipulated responsibility. The application of AI at this time was confined to telecommunication equipment that connected one district with another. Voice recording system, communication media, telephones and telegram have become important communication tools for the people. Hence, continuing efforts by LAs to improve the communication system, which was a form of urbanisation service, was given priority at that time (Hussiin, 2009).

\subsection{The New Economic Policy (DEB) era (1970-1990)}

After the country was rudely awakened by the racial conflict on 13 May 1969, the NEP was introduced. This policy plays a historically significant role in the government's focus on re-organising society by bridging the income and poverty gap highlighted by the conflict. This policy was the first framework for long-term planning in Malaysia. The prevailing conditions around cities became the focus of people who wanted to explore a better quality of life (Gomez and Saravanamuttu, 2013; Milne, 1986). In line with computer and digital technology developments, urban services in delivery, enforcement, monitoring and community services in many Malaysia's cities improved. This was more evident at the end of the 1980s. Hence, because of the importance of urban services 
to the people, the Local Government Act 1976 and the Rural and Planning Act 1976 scrutinise the types of urban services that should be introduced to the city's population. Besides providing the best services to the urban population, the local government enforced by-laws to collect taxes, determine rentals and other charges related to services rendered and the possession of financial self-autonomy. Also, they were given the authority to organise, control and plan all forms of land and building development under their jurisdiction, initiate, assist and encourage collections, maintenance works, bulletins, monographs and other forms of announcements related to rural and town planning according to their methodology. At the end of the DEB era, the National Science and Technology Policy was introduced (1986). This was when the science and technology aspect was officially proclaimed in the national development agenda (Chee, 1990; Seman et al., 2014).

During the DEB era, the application of AI in many urban services systems focused on the LA's duties sector, involving the financial system, documentation, registering consumers and ownership records. However, its implementation was not comprehensive. Examples of AI to consumers include the automatic payment parking system, especially in high-density urban areas such as Kuala Lumpur, Klang Valley, Selangor and Ipoh (Yacob and Khalid, 2012). This system was introduced to help LAs generate their income and other sources, such as imposing a levy on houses and land under their administrative jurisdiction in the form of house assessment and quitting rent payments. The existence of commercial banks around the main cities such as Kuala Lumpur, Ipoh, Johor Bahru, Bandar Melaka and several other cities had offered a more systematic financial system. The population at that time had already been exposed to counterless banking transactions by using automatic teller machines (ATM) for withdrawing their money.

\subsection{The National Development Policy era (1990-2000)}

At this time, the country's economy was stable and strong until the end of 1997 when the economic crisis hit Malaysia. The country's rapid economic expansion had stimulated the use of AI in major sections of the urban services system. Thus, began the emphasis on the aspects of science and technology. These two aspects were seen as important core elements in the planning and development of the urban population's socio-economy, and this required efforts towards developing the capability and capacity in strategic technology and knowledge-based ventures. Assimilating the culture of science and technology into the urban development process requires a form of the modern industrial economy (Khai Leong, 1992; Seman et al., 2014). NDP, among others, was an effort to ensure the country achieved a developed nation status, especially in social inclusivity, efficient government administration and economic excellence. At this time, the rapid development of facilities and infrastructure required the urbanisation administration to design a strategic development plan, specifically for providing the best services for the urban population. It should be remembered that during the NDP era, the existence of new townships progressed rapidly. This situation required LAs to improve their performance by acquiring the latest and most modern delivery and service systems (Balwi, 2005).

This led to the emergence of several technology-based innovation systems for improving the LA's delivery system. The complaint system or the direct dialling telephone system was introduced in some of the main cities in Malaysia, such as DBKL in Kuala Lumpur, Petaling Jaya Municipal Council in Selangor, Shah Alam City Council in Selangor and Johor Bahru Town Council in Johor. The complaint system or the direct dialling telephone system had changed the manner of attracting the city's population to get directly involved in development aspects. Moreover, several systems, such as the Al's financial monitoring system, closed-circuit television (CCTV) security surveillance system and metered parking 
system, were among the types of innovations in the IA delivery system that were introduced in several areas in major cities. However, monitoring was carried out by humans. Based on the sixth and seventh Malaysia Plan, the government made infrastructure, facility development incorporating digital technology and computerisation among the main focus areas, specifically urban development. This is to ensure that economic development in the city continues with its excellent momentum and scintillating phase. Towards the end of the NDP era, the government faced challenges posed by the economic and financial crisis. However, a knowledge-based technological development that needed improvement in the digital technology application aspect had begun to expand exponentially in Malaysia. Several townships had become digital technology hubs, especially for forming informed communities or societies, such as in Petaling Jaya, Subang, Putrajaya and Cyberjaya (Yusoff dan Yaacob, 2010).

\subsection{The information and knowledge-based society era}

This era was known as the knowledge-based social development era. This was when the development of information and communication technology (ICT) found its place and had expanded rapidly among Malaysian cities. Urban society was first exposed to knowledge about ICT at various levels. From the education institutional level right up to the services provided by public and private agencies (Comin and Peng, 2016). Debates concerning the good and bad of information technology development are frequently heard in most cities in Malaysia. All of it revolves around the direction of local services and economic development. During this era, LAs tried to develop internet networking facilities for the majority of the people. Big-name agencies that provide internet services in Malaysia began to appear, such as MAXIS, CELCOM, DIGI, TM, etc. These companies compete for providing network coverage services, mostly in urban areas in Malaysia. This development led to the introduction of online service systems related to most of the services offered in cities. Terminology such as eregister, e-review, e-summons and e-pay began to appear and became important software in many delivery systems operated by LAs in Malaysia (Comin and Peng, 2016). The emergence of these services was due to the government's emphasis on ICT. The ICT changed society's framework and thinking style. The urban society was urged to either by its own accord or otherwise learn about this digital technology. It is said that information can be disseminated, either received or sent, between technology-based equipment with ease. The need for introducing digital technology and AI to urban administration moulded a knowledge-based society, whereby members of this society were characterised as those who use, create, manipulate and disseminate information.

A society characterised by the level of knowledge is important as it translates into a city's state of progress. Also, this provides added value for attracting investors from within and without the country in line with the level of technological advancement found in a city. For example, Cyberjaya is a township that is designed based on AI technology. Petaling Jaya in Selangor is a city generally known to possess the most knowledge-based members of society, and Putrajaya in the Federal Territory is a township specifically designed for providing the best services and facilities to the whole population of Malaysia, while at the same time acting as the federal government's administrative centre. Service systems and infrastructure in these three townships are equipped with all types of the best urbanisation delivery technology for the local society and those living in its surrounding areas.

\subsection{The National Transformation Policy era}

This era saw a peak demand for the transformation of urban services. The national transformation policy brought about a new era in the delivery system of urban services. The introduction of the UTC was well-received by all strata of society in the country 
(Sabel and Jordan, 2015; Malaysia, 2010). The UTC facilitated the government's delivery system, which is a very effective system. Collaboration amongst government agencies to improve the delivery system in UTCs had expedited services and facilitated the city's population when managing daily dealings in a problem-free manner. This is a government effort and initiative to provide various major public and private services for the city's population in a one-stop centre or building. UTC is part of the Blue Ocean Strategy introduced to enhance service quality through strategic collaborations between government agencies and the private sector. Interestingly, UTC is an agglomeration of all government agencies in one building or centre. The city folks do not have to go to numerous places around the city to carry out their official transactions with government agencies. Beginning with birth registrations until the renewal of all travel documents can be carried out in UTCs. The government's initiative is ideal for ensuring that the urban environment is stable, not congested and safe for travel (El-Abidi et al., 2019). Empowering the AI system in UTCs is the driving factor in urban services in Malaysia. Computer technology has been used in most operating systems and the managing of urban services in Malaysia. Providing facilities in cities will fulfil the people's needs, while the various entities in the facilities should be given priority. This section reviewed the history of AI development in Malaysia's urbanisation administration system from the era after independence (1957-1970) to the National Transformation Policy Era.

\section{Artificial intelligence in the urban services and delivery system in Malaysia}

When John McKarthy first highlighted the term AI, his intention was mainly to define it as a computer system that aimed to understand, model and process human thinking and build a machine that can replicate human behaviour. The AI phenomenon has led us to interact with a government service system akin to a child asking something it wants from a father. The government's effort to develop an urbanisation service system capable of offering prompt feedback to consumers is in great demand and should be progressive. People should express their grievances and wants through online communication systems provided at the ministerial level or in most government agencies. This is consistent with Mehr (2017), who argued that government agencies today need to seek AI regarding enhancing their services to the people. Improving the government's delivery system to above par and easily accessed by all strata of society is an important step that ensures society does not feel discriminated against.

Applying AI in urban services implemented by government departments is important for reducing the administrative burden, helping solve problems concerning resources allocation and carrying out complex tasks. All these applications increase the efficiency of the government service and open avenues for employees to build a better relationship with society. Innovations in AI have produced a digital government, which is a step towards narrowing the digital gap, besides increasing the involvement of the population and the quality of the services' delivery system. The use of AI in the government delivery system requires government offices to command six strategies. This is in line withMcCorduck (2004). The strategies are to make AI a part of the programme based on objectives and the people, receive input from the people, design and build based on available sources of information, data should be protected, kept secret and private and constantly tracked, protect ethical risks and avoid decisions made by AI and the need for trained employees to play a role. Presently, there are various types of AI applications, either already in use or planned for some time in the future, and empowering the government's delivery system. This section reviewed the background relevant literature of AI in the urban services and delivery system in Malaysia.
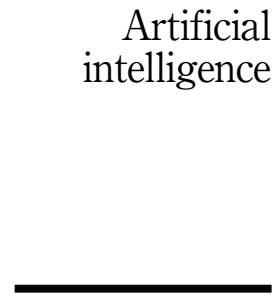
4. Artificial intelligence innovations in Malaysia's urban services

4.1 e-PBT system

Malaysia's urbanisation delivery system is directly related to the LA, better known as LA (PBT). The local council (LC) is the third government entity in the country's administrative structure. LA is the implementer of policies at the grassroots level by directly delivering services to the local community. Generally, the LA is a body incorporated by the Local Government Act 1976 (Act 171), responsible for managing and administrating an area based on local importance. There are 149 LAs in Malaysia, with 99 in Peninsula Malaysia, while 24 in Sabah and 26 in Sarawak, out of which 12 are City Halls/City Councils, 39 are Municipal Councils and 98 are District Councils (Malaysia, 2006a, b). As a frontline agency that deals directly with the people, LA's services provide a picture and perception of the overall government services. Realising the importance of fulfilling the demands of the people who want a more efficient and effective urbanisation delivery system, the government found that using ICT in daily dealings can enhance the quality of LA's delivery system. Hence, e-LA (ePBT) was introduced by integrating AI innovation in the e-LA system, as presented in Figure 3. Introducing e-LA was a proactive step by the government for providing the best programme for the city folks. To ensure that this objective is achieved, guidelines about the LA delivery system were launched (Malaysia, 2012).

The current expansion of the globalisation era has shaped a new direction for urban services throughout Malaysia. It is generally known that the information delivery system and services meant for the city population should be of priority. The present urban services sector

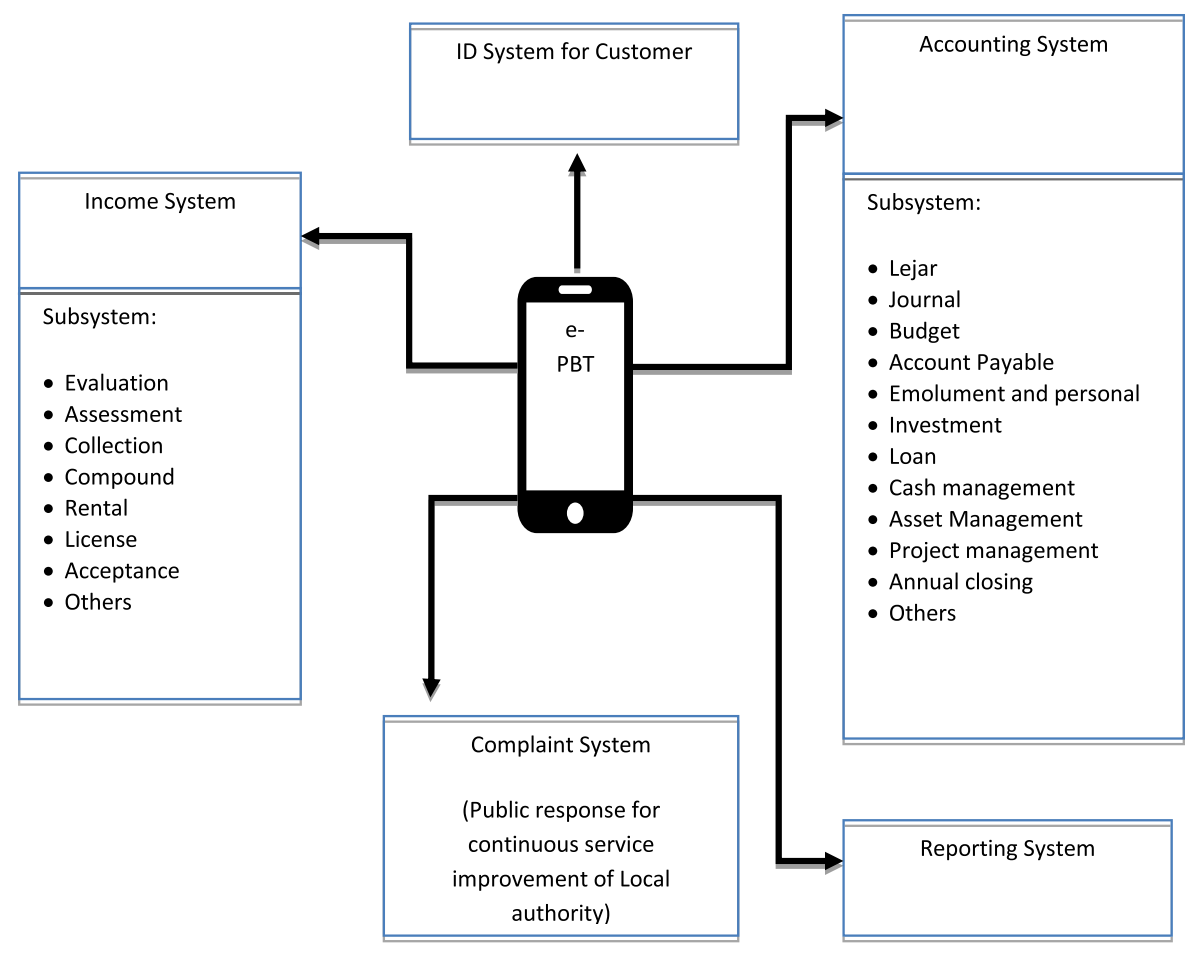

Figure 3.

E-PBT for

enhancement urban services 
is confronted with various challenges due to environmental changes and an increase in people's and business community's expectations. To achieve these aspirations, six core principles of urbanisation service quality were established, which touched on promptness, accuracy, integrity (CTI), productivity, creativity and innovation (PCI) (Malaysia, 2012). Combining AI with ICT in this transformation can create more opportunities for the government to enhance service quality in line with sophisticated technology and the speed of obtaining information at their fingertips. The government service delivery system should emphasise information that fulfils customers' wants and objectives. The LA plays a crucial role in government administration because a LA's image portrays the government's. As a frontline agency, the LA has a direct effect on the people's quality of life, such as roads, traffic lights, licensing, drainage and irrigation systems and refuse (waste) collection (Malaysia, 2012). The LA (PBT) is a frontline agency that frequently deals with developers, business people and investors. Hence, urban services in each LA will become a benchmark for the efficiency and performance of government services. The use of ICT for empowering LA's service delivery is an effort and commitment by the government in ensuring the wishes and agenda of providing the best service to the people becomes a reality.

\subsection{Urban transformation centre (UTC) and artificial intelligence (AI)}

The UTC has brought about revolutionary changes to government services provided to the people. Forming the UTC was an initiative by the sixth Prime Minister, Dato' Seri Najib Tun Razak. It aimed to enhance the level of skills, efficiency and quality of the public service delivery system to the people in line with the slogan, "People First, Achievement Foremost". The formation of the UTC is also consistent with the main element of focus in the National Blue Ocean Strategy (NBOS), called NBOS 6, which lays the foundation for changing society through the Community Transformation Programme (CTP) (Malaysia, 2010). Besides that, NBOS also manages and implements the smart sharing concept in an effort to mobilise various government resources for the people. This was also an effort by the Malaysian government to provide various major government and private sector services in a one-stop centre situated in one building for the benefit of the local urban community. Cugurullo (2021) asserted that the phenomenon of the built environment and governed by urban AI has come to stay. The author affirmed that the complex spectrum of using AI in cities is a unique one.

The Ministry of Finance, Malaysia (MOF) is the ministry leading this programme, and the initiative has succeeded in saving the people's time and costs when acquiring government services. The UTC was introduced to enhance the quality of government services through strategic collaborations between various government agencies, including the involvement of the private sector (UTC, 2020). This is consistent with the ninth Malaysia Plan (RMK-9), centred on the premise that an effective government delivery service system is the key to the successful implementation of social and economic programmes formulated by the government (Malaysia., 2006a). There are 14 branches of the UTC throughout Malaysia, which offer various services to the public under one roof. UTC Melaka, situated in Jalan Hang Tuah, was the first UTC to be formed in Malaysia in 2012. Among the services offered are those by the Immigration Department, Malaysia (JIM), MyEG-HOI, Road Transport Department (JPJ), National Registration Department (JPN), Inland Revenue Board (LHDN), National Higher Education Fund Corporation (PTPTN), Public Land Transport Commission (SPAD) and Company Commission Malaysia (SSM) (UTC, 2020).

In association with contemporary technological advancements and the Industrial Revolution 4.0, a part of UTC operations also applied AI and the overall information technology facilities help to facilitate the public's dealings in the UTC. AI refers to a programme that is used to examine the capabilities of machines, software or robots to learn human behaviour and provide human-like responses or thinking (Shabbir and Anwer, 2015; Ebekozien and Aigbavboa, 2021). Presently, AI programmes are widely used and have led to 
the creation of spectacular technology in the form of smartphones, laptops, drones, automatic machines, self-driving vehicles and robots. Social media applications such as Facebook, YouTube; Google, Yahoo (search applications), Waze, Google Maps (navigation applications) and Alexa, Siri, Cortana, Google Assistant (smart voice application) are examples of AI that have been implemented in various forms. Countries around the world are still competing to develop better versions of AI. Among the leading countries in AI use are the USA, China, Canada, Russia and Germany (Nawi, 2019).

Although AI development programmes in Malaysia are still at the initial stages, Malaysia is striving to expand the use in various government and private sectors, including the UTC (UTC, 2020). For example, the application and renewal of identity cards, passports and road taxes took several days to process. However, nowadays, the process can be settled within an hour on the same day. Besides that, the online passport renewal system is being tested, and it is an innovation in the transformation of the government delivery service system, which affords convenience for all parties involved. AI, which uses MIMOS Big Data Analytic technology and the public data storage system (cloud storage), has been extensively used and integrated into the service system provided in the UTC through various e-government systems. For example, ByrHASIL system, e-Daftar, e-Data PCB, e-Data Praisi, e-Filing, e-Filing CKHT/WHT, e-updating, e-Lejar, e-PCB, e-Residence, e-SPC, PCB Calculator, STAMPS, TAeF, MITRS, Insurance and Takaful Online, SSPN-i Plus Online and many more (UTC, 2020). The GTP stated that the e-government system strengthens governance, facilitates people's affairs and enhances government agencies' productivity and efficiency. In addition, this program also targets the government's creation of a digital document and online business management system (Government Transformation Programme, 2010). Currently, the government is vigorously pursuing efforts to empower AI in urban development. This is apparent in the strategic plan proposed by the Ministry of Human Resources in the 12th Malaysia Plan, which emphasises the application of Big Data Analysis and AI (Ministry of Human Resource Development, 2020). The tenth Malaysia Plan focused on the issue of ICT for facilitating the system and benefitting technology for improving the delivery system and the relationship between the government and both, the people and businesses. This again justified one of the reasons for this review and brought to the front line of the research world for further investigation and feasible solutions to promote IA in urban services delivery across Malaysia and other developing countries.

\subsection{Urban services in a smart city and artificial intelligence}

Cugurullo (2021) described the term city as the ultimate form of a human community. A smart city or intelligent city is a city that monitors and integrates all critical infrastructure, such as transport, communication, human resources management and security services, with the city built based on the smart city management concept that touches on governance, education, economy and community aspects (Hall, 2000; Giffinger et al., 2007). Karvonen et al. (2018) opined that the world is in the era of smart city. Modern urban projects around the globe incorporate smart urbanisation in their projects. Such a city contains all aspects of city development, such as human capital, social as well as traditional and modern infrastructure, help stimulate sustainable economic growth, increase the quality of life and efficient use of human resources through government involvement (Caragliu et al., 2009; Schaffers et al., 2012; Wong et al., 2006). A smart city is also known as a city that uses ICT as well as sophisticated technology to develop the city and handle urbanisation issues. Every city desires to be a smart urban city (Karvonen et al., 2018). The formation or creation of a smart city is caused by the rapid development of the urbanisation process, which in return causes numerous issues related to urbanisation, such as traffic congestions, environmental pollution, human congestion, security issues and a decline in natural resources (Leonteva et al., 2018). 
Barns (2019) avowed that stakeholders are becoming increasingly aware of cities design, experience and governance via urban cultural geography, digital strategy, urban policy and media history. These variables shape a multi-disciplinary approach in an ecosystem's cities.

In a global context, besides being an approach for solving urbanisation issues, a smart city is meant to fulfil national and global agendas. Thus, following the latest global development trends improves the economy and puts Malaysian cities on par with other big cities around the world. In addition, it has an approach for making a city more sustainable and safer for living. Technological advancements and human consumption make a smart city more practical and offer more facilities to the community and the city planner (Yasmin et al., 2016). In the Malaysian context, the need for a smart city is to overcome the challenges of a city, namely, an increasing population and rapid development, which has caused various issues and challenges about urbanisation. Among the issues and challenges is Malaysia's population density estimated to increase from $74.3 \%$ in 2015 to $79.6 \%$ in 2025 . This figure is estimated to increase by not more than $85 \%$ in 2040 . The effect of a high population density leads to urbanisation issues that frequently occur, as mentioned above, such as traffic congestion, environmental pollution and a waste of natural resources. Hence, the initiative to build a smart city that uses contemporary technology will help utilise resources, sustainable management of sources, use of environmental-friendly infrastructure, reduce congestion in the city and improve the city community's quality of life (PLANMalaysia, 2019).

The smart city development initiative intends to enhance the digital economy, which is currently the government's focus. This is because the sector had contributed towards $17.8 \%$ of the KDNK in 2015 and is expected to reach $20 \%$ in 2020. Among the infrastructure that should be of focus when enhancing the country's digital economy are transport, education, health, communication, human resources, business and digital media. Technology, such as the internet of things (IoT), big data, cloud computing, AI and geographic information system (GIS), does have an impact on policies and urban management, integrating information as well as improving the level of services. According to EasyPark Smart Cities Index (ESCI) (2017), Kuala Lumpur is ranked 84 on the list of smart cities in the world. This index is measured based on indicators, such as digital technology, transportation and mobility, economic innovation, governance, urban sustainability and the city community's quality of life. Hence, creating of a smart city in this country can help put Malaysian cities on par with big cities around the world (PLANMalaysia, 2019). Besides enhancing the city community's quality of life in Malaysia, the smart city development initiative fulfils the demands of the global agenda, such as Sustainable Development Goals (SDGs), and the New Urban Agenda (NUA) and the UN Habitat (Kuala Lumpur Declaration on Cities, 2030), which helps the country achieve sustainable development. This initiative also fulfils the demands of the national agenda, which also emphasises sustainable development, such as the 11th Malaysia Plan, National Physical Plan 3 (NPP3), National Urbanisation Plan 2 (NUP2), Vision 2020, Green Technology Master Plan Malaysia 2017-2030 and Low Carbon Cities Framework (Malaysia, 2010; PLANMalaysia, 2019).

Several urban areas in Malaysia have become pilot cities, which would be later developed into smart cities, such as Kuala Lumpur, Johor Bahru, Cyberjaya and Putrajaya. Among the criteria for becoming a smart city in Malaysia are Smart Governance, Smart people, Smart Digital Infrastructure, Smart economy, Smart Mobility, Smart Living, and Smart Environment (Malaysia., 2010; PLANMalaysia, 2019). As for Smart Living, among the examples of this type of development in this country is in Johor, namely, the Rumah Iskandar Malaysia and Inneonusa Sdn Bhd. The Rumah Iskandar Malaysia is based on the concept of a transit house with a moderate density of 25 units per acre, and it focuses on more open space and complete facilities for the community. The objective of building the Rumah Iskandar is to provide better housing with improved public facilities in a more conducive surrounding (Iskandar Malaysia, 2011). Whereas, Inneonusa Sdn Bhd, in collaboration with Telekom 
Malaysia Bhd (TM), UEM Sunrise and Iskandar Investment Bhd, had established a joint operations centre for operating the IoT about smart city services. Inneunusa Sdn Bhd is a company that develops projects around Johor, specifically around the Iskandar Malaysia area, in effort to develop smart cities. Besides the abovementioned projects, Inneonusa Sdn Bhd also developed Smart City Urban Design Guidelines (SCUDG) and Smart City Centralised Monitoring Services (SCCMS) to create a smarter living experience in Iskandar Puteri, Johor (Property Guru, 2018; Inneonusa, 2020). Inneonusa Sdn Bhd also developed the INNEONUSA Command Centre, which is a security system developed for monitoring security and traffic movements (The Star, 2016; Inneonusa, 2020).

Regarding Smart Government, among the projects that supports this initiative is the PJ Smart centre, which manages and monitors Petaling Jaya City more efficiently through dashboard displays and e-perolehan (electronic procurement) application provided by the Malaysian government for facilitating and expediting registration matters, tender appointments and payments to suppliers as well as online services. Whereas, for Smart Economy, the Smart Putrajaya Cashless project was developed to facilitate business matters using QR Pay in collaboration with Bank Muamalat. Meanwhile, the Media and Creative Village programme is located in Pinewood Iskandar Malaysia Studios, whereby this programme trains local film crews to work with big-time international film producers. Smart Mobility includes projects, such as the Cyberjaya Smart Traffic Analytics and Recognition System, a system based on IoT, which allows the modification of the current traffic light system and smoothens traffic flow. The Selangor Smart Bus project provides free Wi Fi facilities in buses, while Flexi Parking is a parking payment system that uses the smart telephone system. The free Wi Fi services project, in collaboration with TM is primarily meant for people living in Putrajaya and the Putrajaya Open Innovation (POINT) programme, encourages community involvement in technology development and is among the projects that support the Smart People initiative.

The Smart Digital Infrastructure is the forte of a smart city, and the internet speed allows the use of the latest technology, especially technology related to infrastructure and utilities, such as IoT, AI, Smart Grid, etc. (PLANMalaysia, 2019). In addition, Alibaba Cloud is a subsidiary of the Alibaba Group dealing with computers. It has made Kuala Lumpur one of the cities to implement the smart traffic management system using the City Brain system. This project was implemented in collaboration with Sena Traffic Systems (SENA), a local traffic system manager. Malaysia is the first country to implement the City Brain system outside of China, and this is consistent with the national digital transformation agenda aimed at empowering technology in Malaysia. This system digitally manages the traffic infrastructure by using AI technology based on public computerisation, and it has the potential to reduce travel time by $12 \%$ (Mohd Zaky, 2019). In China, the concept of City Brain emerged because of geometric urban modernisation. It has enhanced the need for urban governance (Liu et al., 2022). The authors affirmed that the benefits of urban governance via City Brain as a new modern cannot be over-emphasised. There are challenges and pain points in urban governance. The City Brain concept has enhanced urban governance digitalisation to improve urban governance and improve digital, intelligent and modern development of city governance (Caprotti and Liu, 2020). The authors affirmed that the City Brain reflects how Chinese technology corporations developed and marketed smart city products that are both city-specific and could be modified and used for other Chinese cities. This section reviewed different AI innovations in Malaysia's urban services such as e-PBT system, UTC and urban services in a smart city.

\section{Urban services challenges in Malaysia's towards artificial intelligence (AI) technology}

The use of AI technology in urban services also contributes to the re-definition of an urban area. Generally, the urban definition is closely related to the size of the population in a certain 
area. However, some countries have a different definition of a population (Davey, 1993). In Malaysia, urbanisation is defined according to population size, area size, facilities provided, total income and role as a centre of administration, security and education. Current developments in AI in urban areas in Malaysia have contributed towards a definition of new urban areas, such as intelligent and cyber cities. These developments have broadened the definition indicators of a city, such as facilities and infrastructure, fibre optic networks, etrade centres, high-speed broadband facilities, 5D network coverage and other electronic facilities, that apply the AI elements in its operations. Malaysia faces a challenge to develop AI technology in a holistic manner, which entails a high technological cost from the development aspect. Implementing AI-based technology usually requires huge capital, and some LAs, such as the smaller LAs, in Malaysia cannot afford to apply electronic technology and AI. This scenario indicates that this sector still requires support from the government, without which it will experience massive losses and bear huge debts to pay for machinery or robots (Cugurullo, 2020). Besides that, although sophisticated technology can improve productivity in various industries, it can also cause increases in LA management costs if there is damage to machinery, software or support elements since the organisation fully relies on technology for its operations (Garcia, 2021; Gil-Alonso et al., 2021; Kearns and Paddison, 2000).

The unpreparedness of skilled workers and experts at the LA level to manage or monitor the urban services' electronic monitoring system, especially those involving robotics and AI, is one of the challenges (Gil-Alonso et al., 2021). This is important because a high-tech industry needs highly skilled workers (knowledge workers) who are knowledgeable in the field of science and technology. In efforts to face these challenges, the government has emphasised on the technical and professional teaching (TVET) education to fulfil the need for a highly skilled work force. The implementation of TVET focuses on developing skills training in the younger generation. This will create highly skilled workers or a skilled workforce, on par with developed nations (Hussin, 2017; Kearns and Paddison, 2000). Moreover, high-tech industries are inclined to use a limited workforce, which leads to an increase in the unemployment rate (Cugurullo, 2020). This is because the industry uses robotics, computers and other digital communication equipment. Hence, the need for a human workforce is gradually decreasing, and this workforce is being side-lined in the new economic system. This section articulated major urban services challenges facing Malaysia's AI technology.

\section{Limitations and future direction}

This reviewed paper's analysis is limited because of the methodology employed. One of the justifications was filling the gap of reviewed papers that captured AI and urban services in developing countries using Malaysia as a case study. But, this does not compromise the strength of the study. Much is required to be known concerning AI application in urban services in developing countries. AI application during design in the mitigating pandemic spread is one area that should be investigated in the future. What role can AI play in building design to mitigate the spread of pandemic? Evaluating the role of the government in promoting $\mathrm{AI}$ in urban services is one area that future scholars need to explore. Also, future studies need to be considered as part of the implications for future research using mixedmethods research design approach. Ebekozien et al. (2018, 2019 and 2020) affirmed that the mixed-methods approach aids the investigators in confirming and clarifying the initial results and increasing the generalisability of the future study's results. Also, this paper recommends that future studies should be tailored towards other developing countries' AI and urban services and possibly conduct a comparison with Malaysia's status. One of the possible outcomes will be to confirm the results from this paper. 


\section{Conclusion}

AI has become a wide and progressive field that has grasped the entire control of artificial and digital technology and robotics. The role of urban services is to organise and provide the best services to urban social life so that its occupants can enjoy a very high quality of life. The emergence of $\mathrm{AI}$ in the urban services system has made the city the focus of human habitat. This has become an important national policy for many countries regarding enhancing urban services. Facing rapid urban development through the local council, most towns in Malaysia have come up with the idea of designing a strategic plan as part of the District Structure Plan and development of the main urban areas. All these are consistent with current government policies. The emergence of a more focused strategic plan in the form of the National Urbanisation Policy and the Malaysian Plan has made AI an undeniably important element in these plans. The findings show that the influence of AI in urban services has long existed and been carefully planned by LAs since colonial times. In addition, the upgrading of AI in urban services in Malaysia is influenced by the development of global digital technology. This paper reviewed the influence of AI on urban services in Malaysia. Also, the challenges facing AI regarding the application in urban services were identified. The findings show that with the improved promotion of AI in urban services via feasible policies across Malaysia, there will be an increased performance of project delivery. Hence, this is one of the justifications for this paper, with some feasible possible solutions to promote and enhance AI usage in urban services in Malaysia. This effort is directly related to local economic development, which can encourage investors to invigorate the urban economy jointly. Lastly, this plan intends to stir the urban social community to enjoy a better quality of life as desired.

\section{References}

Abbott, J. (2013), Sharing the City: Community Participation in Urban Management, Routledge, London.

Balwi, M.K.B.M. (2005), "Pembangunan Luar Bandar Di Malaysia: Gerakan Desa Wawasan (Gdw) Sebagai Mekanisme Pembangunan Masyarakat Luar Bandar", Sains Humanika, Vol. 42 No. 1, pp. 22-29.

Barns, S. (2019), Platform Urbanism: Negotiating Platform Ecosystems in Connected Cities, Springer Nature, London.

Caprotti, F. and Liu, D. (2020), "Platform urbanism and the Chinese smart city: the co-production and territorialisation of Hangzhou City Brain", Geo Journal, pp. 1-15.

Caragliu, A., Del Bo, C. and Nijkamp, P. (2013), Smart Cities in Europe, VU University Amsterdam, Faculty of Economics, Business Administration and Econometrics, Research Memoranda 0048, Amsterdam, 2009 From Moscow to Sao Paulo, Emerging 7 Cities Report.

Chee, W.T. (1990), "Industrial Development, the new economic policy in Malaysia, and the international Division of Labour", ASEAN Economic Bulletin, pp. 106-119.

Choon, S.W., Siwar, C., Pereira, J.J., Jemain, A.A., Hashim, H.S. and Hadi, A.S. (2011), “A sustainable city index for Malaysia", International Journal of Sustainable Development and World Ecology, Vol. 18 No. 1, pp. 28-35.

Comin, D. and Peng, K.K. (2016), "Malaysia: the economic transformation program (B)", World Scientific Book Chapters, pp. 123-129.

Cugurullo, F. (2020), "Urban artificial intelligence: from automation to autonomy in the smart city", Frontiers in Sustainable Cities, Vol. 2 No. 38, pp. 23-29.

Cugurullo, F. (2021), Frankenstein Urbanism: Eco, Smart and Autonomous Cities, Artificial Intelligence and the End of the City, Routledge, London.

Davey, K.J. (1993), Elements of Urban Management, The World Bank. 
Ebekozien, A. (2019), Root Cause Analysis of Demand-Supply Gap to Low-Cost Housing in Malaysia, $\mathrm{PhD}$ thesis submitted to Univeristi Sains Malaysia, Pulau Pinang.

Ebekozien, A. and Aigbavboa, C. (2021), "COVID-19 recovery for the Nigerian construction sites: the role of the fourth industrial revolution technologies", Sustainable Cities and Society. doi: 10.1016/j.scs.2021.102803.

Ebekozien, A., Abdul-Aziz, A.R. and Jaafar, M. (2018), "Low-cost housing leakages in Malaysia: the unexplored dimension”, Pacific Rim Property Research Journal, Vol. 24 No. 3, pp. 249-264.

Ebekozien, A., Abdul-Aziz, A.R. and Jaafar, M. (2019), "Housing finance inaccessibility for low-income earners in Malaysia: factors and solutions", Habitat International, Vol. 87, pp. 27-35, doi: 10. 1016/j.habitantint.2019.03.009.

Ebekozien, A., Abdul-Aziz, A.R. and Jaafar, M. (2020), "Unravelling the encumbrances in the low-cost housing computerised open registration system in Malaysia's major cities", Property Management, Vol. 38 No. 3, pp. 1-19.

El-Abidi, K.M.A., Ofori, G., Zakaria, S.A.S., Mannan, M.A. and Abas, N.F. (2019), "Identifying and evaluating critical success factors for industrialized building systems implementation: Malaysia study", Arabian Journal for Science and Engineering, Vol. 44 No. 10, pp. 8761-8777.

García, D.B. (2021), "Urban policies and Large projects in central city areas: the example of Madrid (Spain)", Urban Science, Vol. 5 No. 2, pp. 42-50.

Giffinger, R., Fertner, C., Kramar, H., Kalasek, R., PichlerMilanoviü, N. and Meijers, E. (2007), Smart Cities: Ranking of European Medium-Sized Cities, Centre of Regional Science (SRF), Vienna University of Technology, Vienna.

Gil-Alonso, F., López-Villanueva, C., Bayona-i-Carrasco, J. and Pujadas, I. (2021), “Towards an even more Spatially Diversified city? New Metropolitan population trends in the Post-economic crisis Period", Urban Science, Vol. 5 No. 2, pp. 41-50.

Gomez, E.T. and Saravanamuttu, J. (2013), The New Economic Policy in Malaysia: Affirmative Action, Ethnic Inequalities and Social Justice, NUS Press, Singapore.

Government Transformation Programme (2010), Government Transformation Programme.

Hall, R.E. (2000), "The vision of a smart city", Proceedings of the 2nd International Life Extension Technology Workshop, Paris, France, Sep 28, available at: http:/www.osti.gov/bridge/servlets/ pur1/773961- oyxp82/webviewable/773961.pdf (accessed 10 June 2021).

Hussiin, H. (2009), "Kesan modenisasi ke atas hubungan kaum di Malaysia”, Jurnal UMP Sains Sosial and Pengurusan Teknologi, Vol. 1 No. 1, pp. 13-22.

Hussin, K.A. (2017), "Industri 4.0 wujudkan 1.5 juta peluang", available at: https://www.bharian.com.my/berita/ nasional/2017/12/360270/industri-40-wujudkan-15-juta-peluang-pekerjaan (accessed 13 June 2021).

Ibrahim, M.R., Haworth, J. and Cheng, T. (2020), "Understanding cities with machine eyes: a review of deep computer vision in urban analytics", Cities, Vol. 96, p. 102481.

Inneonusa (2020), "InneoNusa value creation through smart technology", https://www.inneonusa.com/ \#services (accessed 13 June 2021).

Iskandar Malaysia (2011), "Merealisasikan impian”, Kini Dan Di sini, available at: http:// iskandarmalaysia.com.my/downloads/BMnoCM.pdf (accessed 13 June 2021).

Jenkins, P. (2000), "Urban management, urban poverty and urban governance: planning and land management in Maputo", Environment and Urbanization, Vol. 12 No. 1, pp. 137-152.

Karvonen, A., Federico, C. and Federico, C. (2018), Inside Smart Cities: Place, Politics and Urban Innovation, Routledge, London.

Kearns, A. and Paddison, R. (2000), "New challenges for urban governance”, Urban Studies, Vol. 37 Nos 5-6, pp. 845-850.

Khai-Leong, H. (1992), "Dynamics of policy-making in Malaysia: the formulation of the new economic policy and the national Development policy", Asian Journal of Public Administration, Vol. 14 No. 2, pp. 204-227. 
Leonteva, L., Maksimov, D.A., Kurbanov, S., Afanasev, I.V., Melnikova, T. and Rezakov, R. (2018), "Information services and development of effective urban management", International Journal of Civil Engineering and Technology, Vol. 9 No. 11, pp. 2518-2525.

Liu, W., Mei, Y., Ma, Y., Wang, W., Hu, F. and Xu, D. (2022), "City Brain: a new model of urban governance", in Li, M., Bohács, G., Huang, A., Chang, D. and Shang, X. (Eds), IEIS 2021. Lecture Notes in Operations Research, Springer, Singapore, doi: 10.1007/978-981-16-8660-3_12.

Malaysia (2006a), 9th Malaysia Plan, Prime Minister Department, Kuala Lumpur.

Malaysia (2006b), 171 Act, Local Government Act 1976, Ministry of Local Government and Housing, Kuala Lumpur.

Malaysia (2010), Government Transformation Programme, Prime Minister Department, Kuala Lumpur.

Malaysia (2012), E-PBT. Ministry of Local Government and Housing, Kuala Lumpur.

McCorduck, P. (2004), Machines Who Think: A Personal Inquiry into the History and Prospects of Artificial Intelligence, CRC Press, New York.

McGill, R. (1998), “Urban management in developing countries”, Cities, Vol. 15 No. 6, pp. 463-471.

Ministry of Human Resource Development (2020), National Education Policy 2020.

Milne, R.S. (1986), "Malaysia-beyond the new economic policy", Asian Survey, Vol. 26 No. 12, pp. 1364-1382.

Mohd Zaky, Z. (2019), "Alibaba Cloud, Sena bangun pengurusan trafik pintar”, available at: https:// www.bharian.com.my/bisnes/lain-lain/2019/05/567306/alibaba-cloud-sena-bangun-pengurusantrafik-pintar (accessed 11 June 2020).

Nawi, A. (2019), "Early exploration towards issues and impact the use of artificial intelligence technology towards human beings", Asian Journal of Civilizational Studies (AJOCS), Vol. 1 No. 4, pp. 24-33.

PLANMalaysia (2019), "Perancangan dan Pembangunan Bandar Pintar di Malaysia- Keperluan Alaf Baru. Kertas Kerja 3: Ke arah Pembangunan Bandar Pintar Malaysia”, available at: http://www. planmalaysia.gov.my/index.php/en/seminar/496-kertas-kerja-wacana-ilmu-bandar-pintar (accessed 13 June 2021).

Property Guru (2018), "Inneonusa enables smarter living in iskandar Puteri with the Launch of A smart city urban Design guideline (SCUDG) and smart city centralised monitoring services (SCCMS)", available at: https://www.propertyguru.com.my/property-news/2018/11/176086/ inneonusa-enables-smarter-living-in-iskandar-puteri-with-the-launch-of-a-smart-city-urbandesign-guideline-scudg-smart-city-centralised-monitoring-services-sccms (accessed 13 June 2021).

Russell, S.J. and Norvig, P. (2016), Artificial Intelligence: A Modern Approach.

Sa'at, N.H., Mamat, I. and Nawang, W.M.Z.W. (2017), "Sociocultural change and social mobility among estuarial communities in the east coast of Peninsular Malaysia”, Akademika, Vol. 87 No. 3, pp. 12-19.

Sabel, C. and Jordan, L. (2015), Doing, Learning, Being: Some Lessons Learned from Malaysia's National Transformation Program, World Bank, Washington, DC.

Schaffers, H., Komninos, N. and Pallot, M. (2012), "Smart cities as innovation ecosystems sustained by the future internet", available at: http://www.fireball4smartcities.eu/wp-content/uploads/2012/ 05/FIREBALLWhite-Paper-Final2.pdf (accessed 09 June 2021).

Schalkoff, R.J. (1990), Artificial Intelligence Engine, McGraw-Hill.

Seman, A.A., Hussin, N. and Iqbal, U. (2014), "Sejarah perkembangan pelaburan Jepun di Malaysia 18901980", Jebat: Malaysian Journal of History, Politics and Strategic Studies, Vol. 41 No. 1, pp. 57-93.

Shabbir, J. and Anwer, T. (2015), "Artificial intelligence and its role in near future”, ArXiv:1804.01396 [Cs], Vol. 14 No. 8, pp. 1-11. 
The Star (2016), "M'sia's first ops centre for smart city services now ready", The Star, available at: https://www.thestar.com.my/business/business-news/2016/07/01/msias-first-ops-centre-forsmart-city-services-now-ready (accessed 09 June 2021).

UTC (2020), "UTC", available at: https://www.utc.my/ (accessed 20 June 2021).

Wong, S.W., Tang, B.S. and Van Horen, B. (2006), "Strategic urban management in China: a case study of Guangzhou Development District", Habitat International, Vol. 30 No. 3, pp. 645-667.

Wu, N. and Silva, E.A. (2010), "Artificial intelligence solutions for urban land dynamics: a review", Journal of Planning Literature, Vol. 24 No. 3, pp. 246-265.

Yacob, S. and Md Khalid, K. (2012), "Adapt or divest? The new economic policy and foreign businesses in Malaysia (1970-2000)", The Journal of Imperial and Commonwealth History, Vol. 40 No. 3, pp. 459-482.

Yasmin, S., Zaka, A., Imran, A., Zahid, M.A., Yousaf, S., Rasul, G., Arif, M. and Mirza, M.S. (2016), "Plant growth promotion and suppression of bacterial leaf blight in rice by inoculated bacteria", PloS One, Vol. 11 No. 8, e0160688.

Yigitcanlar, T., Desouza, K.C., Butler, L. and Roozkhosh, F. (2020), "Contributions and risks of artificial intelligence (AI) in building smarter cities: insights from a systematic review of the literature", Energies, Vol. 13 No. 6, pp. 1473-1480.

Yigitcanlar, T., Corchado, J.M., Mehmood, R., Li, R.Y.M., Mossberger, K. and Desouza, K. (2021), "Responsible urban innovation with local government artificial intelligence (AI): a conceptual framework and research agenda", Journal of Open Innovation: Technology, Market, and Complexity, Vol. 7 No. 1, pp. 71-80.

Yusoff, M.N.H.B. and Yaacob, M.R.B. (2010), “The government business support services in Malaysia: the evolution and challenges in the new economic model", International Journal of Business and Management, Vol. 5 No. 9, pp. 60-69.

\section{Further reading}

Bench-Capon, M.J.T. and Dunne, E.P. (2007), “Argumentation in artificial intelligent”, Artificial Intelligence, Vol. 171, pp. 619-641.

Elaine, R., Kevin, K. and Shivashankar, N. (2009), Artificial Intelligence, 3rd ed., McGraw-Hill, London.

Grewal, D.S. (2014), "A critical conceptual analysis of Definitions of artificial intelligence as applicable to computer engineering", Journal of Computer Engineering, Vol. 16 No. 2, pp. 09-13.

Hila, M. (2017), Artificial Intelligence for Citizen Services and Government. ASH Center for Democratic Governance and Innovation, Harvard Kennedy School, Harvard.

Robert, J.S. (1990), Artificial Intelligence Engine, McGraw-Hill, NY.

Stuart, J.R. and Peter, N. (2016), Artificial Intelligence: A Modern Approach, 3rd ed., Person Education, George Town.

Yunhe, P. (2016), "Heading toward artificial intelligence 2.0", Journal of Engineering, Vol. 2, pp. 409-413.

\section{About the authors}

Associate Professor Dr Mohamad Shaharudin Samsurijan is a Lecturer in Development Planning and Management, School of Social Sciences, Universiti Sains Malaysia. Currently, he is Deputy Dean (Academic, Career and International) at School of Social Sciences. He obtained a PhD in Environmental Management from Universiti Kebangsaan Malaysia. His main fields of interest are development studies, urban quality of life and well-being. He is also involved in Social Impact Assessment consultant and research.

Dr Andrew Ebekozien is an Academic Fellow in Development Planning and Management, School of Social Sciences, Universiti Sains Malaysia. He obtained his $\mathrm{PhD}$ in Cost Management from Universiti 
Sains Malaysia, Malaysia. Andrew Ebekozien is the corresponding author and can be contacted at: ebekoandy45@yahoo.com

Dr Noor Alyani Nor Azazi is a Senior Lecturer in the Development Planning and Management Section in the School of Social Sciences, Universiti Sains Malaysia. Her research interests revolve around urban development, the influence of higher learning institution on urban development and experience economy.

Dr Maslina Mohammed Shaed is a Senior Lecturer at the School of Social Sciences, Universiti Sains Malaysia. Her research interests are mainly in management, gender and development, human resource development, developmental science, human science development and urban community development.

Dr Radin Firdaus Radin Badaruddin is a Senior Lecturer in the Department of Planning and Management, School of Social Sciences, Universiti Sains Malaysia. His areas of research include food security, agricultural development and policy, climate change adaptation measures and sustainable development.

For instructions on how to order reprints of this article, please visit our website: www.emeraldgrouppublishing.com/licensing/reprints.htm Or contact us for further details: permissions@emeraldinsight.com 